Physics and Chemistry of the Earth

Vol. 3. Edited by Prof. L. H. Ahrens, Frank Press, Kalervo Rankama and S. K. Runcorn. (Progress Series.) Pp. viii +464. (London and New York: Pergamon Press, 1959.) 100s. net; 15 dollars.

7 HIS volume contains admirably concise chapters by J. W. Durham on palæoclimates, by A. G. W. Cameron on the origin of the elements and by D. C. Tozer on the electrical properties of the Earth's interior. S. I. Tomkeieff, in "Geochemistry in the U.S.S.R. (1954-1956)" gives a partially annotated bibliography of about 1,200 titles which is an extremely useful list of Russian publications dealing with igneous, metamorphic and sedimentary rocks, geochemistry, cosmochemistry, mineralogy and natural waters. It is a sad reflexion on the state of scientific libraries in Britain that some of those publications are unobtainable anywhere in this country. The geochemistry of thorium and uranium is reviowed by J. A. S. Adams et al., while in "Silicate Molt Systems" E. Roedder reproduces about sixty phase-diagrams dealing with various portions of the geologically important system $\mathrm{K}_{2} \mathrm{O}-\mathrm{Na}_{2} \mathrm{O}-\mathrm{CaO}-$ $\mathrm{FeO}-\mathrm{MgO}-\mathrm{Fe}_{2} \mathrm{O}_{3}-\mathrm{Al}_{2} \mathrm{O}_{3}-\mathrm{SiO}_{2}$, and he gives a helpful summary of the experimental techniques used. Unfortunately there is no attempt to relate the diagrams to petrology in the way pioneered by $\mathrm{N}$. Bowen moro than thirty years ago.

Noarly half the book deals with geophysical investigations in the eastern Caribbean by C. B. Officer et al. and the continental margin of the oast coast of North America, north of Cape Hatteras, by C. L. Drake et al. Much undigested detail quite unsuitable for a general reviow is contained in both these articles, and this has probably been the chief cause of the increased price (100s.) compared with either Vol. 1 (70s.) or Vol. $2(63 s)$. For oxample, the former article contains no less than 55 pages of seismic profiles and their interpretation whilo the latter contains 13 pages on 'significant' boreholes in eastern America and the important basement rocks encountered ('decomposed rock' ; 'bedrock' ; 'crystalline rock'), various figures and text, all of which fail to give the reader a picture of tho basement.

B. E. LEAKE

The Measurement of Grassland Productivity

Proceedings of the University of Nottingham Sixth Easter School in Agricultural Science, 1959. Edited by Prof. J. D. Ivins. Pp. viii +217 . (London: Butterworths Scientific Publications ; New York : Academic Press, Inc., 1959.) 35s. ; 7 dollars.

FOR several years the University of Nottingham 4 has organized an Easter School in a branch of agricultural science. At the 1959 School, on measuring grassland productivity, 20 papers were given, which are published in this book, together with summarios of the discussions.

Grass occupies two-thirds of British farmland, but current production from it is much less than would be possible if existing knowledge of improved varieties, fertilizers and techniques of management were fully applied. Lack of confidonco in methods for measuring grasslund productivity hinders these developments and this School was organized to review and discuss current methods.

In the opening session Dr. William Davies reviewed tho history of methods of measuring grassland output ; corresponding German work during the past twenty years was described by Prof. F. Klapp, T. E. Williams then gave a good account of the effect of leys on the productivity of arable crops grown after the leys were ploughed.

A second group of papers dealt with the growth characteristics of different herbage crops and the problems of assessing thoir relative merits. Herbage has no true value until it has been used by an animal, so the third group of three papers discussed methods of assessing how much grass is actually eaten by stock in grazing experiments. Eight papers dealt with assessments of animal production from grass, and with correlating estimates of pasture growth with the performance of animals using the herbage. Three of these papers discussed the digestibility of herbage in pasture experiments.

Two papers described farm-scale measurements. Work done by Imperial Chemical Industries, Ltd., on commercial farms showed that measurements of grassland production must be rolated to output, from the whole farm business; single measurements of productivity, and particularly physical measurements, can be misleading. Mr. Rex Patterson showed how his farm records of grazing have been used to measure pasture productivity and also quality.

The papers cover the subject woll although their quality varies ; together they provide a good review and the book is recommended to those concerned with scientific work on grass.

G. W. CoOKE

\section{Handbook of Toxicology}

Vol. 3 : Insecticides : a Compendium. By William O. Neghorbon. Prepared under the Direction of the Committee on the Handbook of Biological Data, Division of Biology and Agriculture, National Acadomy of Scionces-National Research Council. Pp. xxv + 854. (Philadelphia and London: W. B. Saunders Company, 1959.) 98s. net.

THE insecticides volume of the "Handbook of Toxicology" is an impressive production which is well calculated to save an immonse amount of time for anyone seeking the available information about the great range of chemicals that are in use as insecticides and synorgists at the present time. The contents are arranged alphabetically under the preferred chemical names of the substances. But intorsporsed among these are general articles on such subjects as anti-metabolites, bees and insocticides, cytochrome oxidase (effoct of insecticides on), resistance, tomperaturo and insecticidal action and others. Some of these sections help to lighten the subject-matter, as do the introductory sections dealing with each insecticide or group of insecticides. Under a given substance will be found an account of its chemistry ; toxicity for man and wild-life; toxicity for insects; factors influencing toxicity; ontry and mode of action in the insect; formulations ; resistance ; all these subjects being illustratod by exhaustive compilations of tabulated data. An insecticide such as DDT on which a vast literature exists will have about 40 pages devoted to it. Original roferences are quoted for every pioce of information; the referonce list contains 3,404 titles. There are separate indexes to chemical compounds, and to the scientific and common names of insects.

This should prove a most valuable work of reference. The short general introductions to the various soctions can be read with interost by anyone looking for a broad survoy of tho subject.

V. B. WiggLesworTII 